\title{
Penerapan Model Kooperatif Tipe Two Stay Two Stray (TSTS) dalam Upaya Meningkatkan Kemampuan Pemecahan Masalah Matematis Siswa SD
}

\author{
Suraji ${ }^{1}$, Arnida Sari ${ }^{2}$ \\ ${ }^{1}$ SD Negeri 136 Pekanbaru \\ 1,2 Mathematics Education, Universitas Islam Negeri Sultan Syarif Kasim Riau \\ e-mail: suraji6276@grad.unri.ac.id \\ arnidasari@uin-suska.ac.id
}

\begin{abstract}
ABSTRAK. Penelitian ini bertujuan untuk meningkatkan kemampuan pemecahan masalah matematis siswa kelas V SD Negeri 136 Pekanbaru. Jenis penelitian ini merupakan penelitian tindakan kelas dengan subjek penelitian adalah kelas V.B yang berjumlah 35 orang. Pengambilan data dalam penelitian ini menggunakan dokumentasi, observasi, dan tes. Penelitian ini dilakukan sebanyak tiga siklus, yang masing-masing terdiri dari kegiatan perencanaan, pelaksanaan, pengumpulan data dan refleksi. Pada siklus I, diperoleh hasil belajar siswa rata-rata $20 \%$ dan siklus II sebesar $60 \%$. Sedangkan pada siklus III terdapat peningkatan kemampuan pemecahan masalah matematis menjadi $80 \%$. Teknik analisis data yang digunakan pada penelitian ini adalah analisis statistik deskriptif. Hasil penelitian menunjukkan suatu peningkatan dari siklus pertama ke siklus selanjutnya, baik dari segi proses pembelajaran maupun kemampuan pemecahan masalah matematis siswa. Berdasarkan hasil penelitian dapat disimpulkan bahwa penerapan model kooperatif tipe TSTS dapat meningkatkan kemampuan pemecahan masalah matematis siswa kelas V.B SD Negeri 136 Pekanbaru.
\end{abstract}

Keywords : two stay two stray, kemampuan pemecahan masalah, matematika

\section{PENDAHULUAN}

Pendidikan sangat erat kaitannya dengan pembelajaran karena pendidikan merupakan usaha manusia untuk mengubah dan membina kepribadian berlandaskan dengan nilai-nilai baik di dalam masyarakat maupun kebudayaan. Manusia memperoleh ilmu pendidikan yang dapat dijadikan tuntunan dalam kehidupan dan dengan pendidikan orang menjadi maju serta mampu bersaing dengan Negara lain dalam segala bidang. Trianto (2012) mengutip bahwa tujuan pendidikan nasional yaitu untuk mengembangkan kemampuan dan membentuk watak serta peradaban yang bermartabat dalam rangka mencerdaskan kehidupan bangsa, agar menjadi manusia yang beriman dan bertaqwa kepada Tuhan Yang Maha Esa, berakhlak mulia, sehat, berilmu, cakap, kreatif, mandiri dan menjadi warga negara yang demokratis serta bertanggungjawab. Matematika merupakan ilmu dasar dalam kehidupan manusia yang memiliki peranan penting. Menurut Cockrof "matenatika sangat dibutuhkan dan berguna dalam kehidupan sehari hari, bagi sains, perdangangan dan industri”" (Uno, 2008).

Tujuan yang dicapai dalam pelajaran matematika menurut National Council of Teacher of Mathematics (NCTM) tahun 2000 adalah siswa harus memiliki lima kemampuan matematis, satu diantaranya adalah: belajar untuk memecahkan masalah (mathematical problem solving). Mulyono (2012) menyatakan bahwa pemecahan masalah biasanya melibatkan beberapa kombinasi konsep dan keterampilan dalam suatu situasi baru atau situasi berbeda. Maka pemecahaan masalah adalah 
aplikasi dari konsep dan keterampilan. Sedangkan Wena (2011) menyatakan kemampuan pemecahan masalah dipandang sebagai suatu proses untuk menemukan kombinasi dari sejumlah aturan yang dapat diterapkan dalam upaya mengatasi situasi yang baru. Sehingga pemecahan masalah merupakan bagian dari tujuan pembelajaran matematika yang sangat penting karena dalam proses pembelajaran maupun penyelesaiannya, siswa dimungkinkan memperoleh pengalaman menggunakan pengetahuan serta keterampilan yang sudah dimiliki untuk diterapkan dalam pemecahan masalah yang bersifat tidak rutin.

Proses pemecahan masalah tersebut dilakukan oleh siswa, ketika siswa dihadapkan pada persoalan yang mereka temukan sendiri atau masalah yang sengaja diberikan dalam proses pembelajaran. Tujuan penggunaan metode ini adalah memberikan kemampuan dasar dan teknik kepada siswa agar mereka mampu memecahkan masalah, ketimbang hanya diceikoki dengan sejumlah data atau informasi yang harus dihafalkan. Dengan kata lain, guru memberikan bekal pada siswa tentang kemampuan untuk memecahkan masalah dengan menggunakan kaidah ilmiah tentang teknik, langkah-langkah berpikir kritis dan rasional. Ini ditegaskan oleh Suyanto (2012) bahwa bekal kemampuan tentang kaidah dasar dan teknik-teknik pemecahan masalah tersebut akan sangat bermanfaat bagi siswa untuk diterapkan dalam proses pemecahan masalah dalam kehidupan sehari-hari. Melalui kegiatan ini aspek-aspek kemampuan matematika penting seperti penerapan aturan pada masalah tidak rutin, penemuan pola, penggeneralisasian, komunikasi matematik, dan lain-lain dapat dikembangkan secara lebih baik.

Mempelajari penyelesaian masalah adalah tujuan utama mempelajari matematika karena penyelesaian masalah merupakan satu aspek dalam kehidupan yang pasti dihadapi (Zakaria, 2007 :112). Jadi, pemecahan masalah matematika adalah kemampuan yang dimiliki oleh siswa dalam menggunakan pengetahuan serta keterampilan yang sudah dimiliki untuk diterapkan pada pemecahan masalah demi menemukan jawaban-jawaban atas masalah yang siswa hadapi dalam pembelajaran matematika.

Masalah dalam matematika dapat diklasifikasikan menjadi beberapa masalah. Menurut Krulik dan Rudnick sebagaimana yang dikutip Effandi Zakaria, menyatakan bahwa masalah dalam matematika dapat diklasifikasikan menjadi dua jenis (Zakaria, 2007 : 112), yaitu:

1) Masalah rutin merupakan masalah berbentuk latihan yang berulang-ulang yang melibatkan langkah-langkah dalam penyelesaiannya.

2) Masalah yang tidak rutin yaitu ada dua:

a) Masalah proses yaitu masalah yang memerlukan perkembangan strategi untuk memahami suatu masalah dan menilai langkah penyelesaian masalah tersebut.

b) Masalah yang berbentuk teka teki yaitu masalah yang memberikan peluang kepada siswa untuk melibatkan diri dalam pemecahan masalah tersebut.

Berdasarkan yang terjadi di kelas, didapatkan bahwa siswa masih mengalami kesulitan dalam menyelesaikan soal pemecahan masalah. Hal ini terlihat ketika diberikan latihan soal dalam bentuk soal cerita. Siswa mengalami kesulitan ketika mengerjakan soal yang berbeda dari contoh soal yang diberikan guru, sebagian besar siswa hanya menghafalkan rumus tanpa memahami proses mendapatkan rumus tersebut, mereka sulit menyusun rencana untuk melengkapi data-data yang dibutuhkan menggunakan informasi yang diketahui; selain itu, jika diberikan soal cerita dengan data-data pengecoh, sebagian besar siswa terkecoh dan menganggap bahwa semua data yang diberikan pada soal harus digunakan untuk menemukan solusi.

Karena pemecahan masalah merupakan kegiatan matematika yang sangat sulit baik mengajarkannya, maka sejumlah besar peneliti telah difokuskan pada pemecahan masalah matematika. Dari berbagai hasil penelitian, antara lain diperoleh beberapa kesimpulan sebagai berikut (Suherman, $2001: 88$ ) .

1) Strategi pemecahan masalah dapat secara spesifik diajarkan.

2) Tidak ada satupun strategi yang dapat digunakan secara tepat untuk setiap masalah yang dihadapi. 
3) Berbagai startegi pemecahan masalah dapat diajarkan pada siswa dengan maksud untuk memberikan pengalaman agar mereka dapat memanfaatkannya pada saat menghadapi berbagai variasi masalah.

4) Siswa perlu dihadapkan pada berbagai permasalahan yang tidak dapat diselesaikan secara cepat sehingga memerlukan upaya mencoba berbagai alternatif pemecahan.

5) Kemampuan anak dalam pemecahan masalah sangat berkaitan dengan tingkat perkembangan mereka.

Untuk dapat mengajarkan pemecahan masalah dengan baik, ada beberapa hal yang perlu dipertimbangkan antara lain, waktu yang digunakan untuk pemecahan masalah, perencanaan, sumber yang diperlukan, peran teknologi, dan manajemen kelas (Suherman, $2001: 90)$.

1) Waktu

Waktu yang diperlukan untuk menyelesaikan masalah sangatlah relatif. Jika seseorang dihadapkan pada suatu maslah yang diberikan untuk menyelesaikannya tidak dibatasi, maka kecendrungannya orang tersebut tidak akan mengkonsentrasikan pikirannya secara penuh pada proses pemecahan masalah yang diberikan. Sebaliknya, jika seseorang dalam menyelesaikan suatu masalah dibatasi oleh waktu yang ketat, maka seluruh potensi pikirannya mungkin akan dikonsentrasikan secara penuh pada penyelesaian soal tersebut. Dengan demikian, upaya untuk mendorong siswa agar mampu memanfaatkan waktu yang disediakan dalam proses pemecahan suatu masalah merupakan hal yang perlu dikembangkan dari waktu ke waktu. Beberapa hal yang perlu dikembangkan dalam kaitanya dengan waktu antara lain adalah: waktu memahami masalah, waktu untuk mengeskplorasi liku-liku masalah, dan waktu untuk memikirkan masalah.

2) Perencanaan

Aktivitas pembelajaran dan waktu yang diperlukan harus direncanakan serta dikoordinasikan sehingga siswa memiliki kesempatan yang cukup untuk menyelesaikan berbagai masalah, dan menganalisis serta mendiskusikan pendekatan yang mereka pilih.

3) Sumber

Karena buku-buku matematika biasanya banyak membuat masalah yang sifatnya rutin, maka guru harus memiliki kemampuan untuk membangkitkan masalah-maslah lainnya sehingga dapat menambah koleksi soal pemecahan masalah bagi kebutuhan pembelajaran. Salah satu strategi yang dapat digunakan untuk meningkatkan koleksi soal pemecahan masalah antara lain sebagai berikut:

a) Kumpulkan soal-soal pemecahan masalah dari koran, majalah, atau buku-buku selain buku peket.

b) Membuat soal sendiri misalnya dengan menggunakan ide yang datang dari lingkungan, koran, atau televisi.

c) Memanfaatkan situasi yang muncul secara spontan khususnya yang didasarkan atas pertanyaan dari siswa.

d) Saling tukar soal sesama teman guru.

e) Mintalah siswa untuk menuliskan soal yang dapat dipertukarkan sesama siswa. Mungkin di antara soal-soal itu ada yang layak untuk dikoleksi.

4) Teknologi

Walaupun sebagian besar kalangan ada yang tidak setuju kalkulator digunakan di sekolah, akan tetapi dengan membatasi penggunaannya hanya pada hal-hal tertentu, alat tersebut perlu dipertimbangkan pengguaannya. Karena kalkulator dapat digunakan untuk membantu mempercepat perhitungan rutin, 
maka siswa dapat difokuskan pada kegiatan pemecahan masalah, dengan kalkulator sebagai alat bantu. Alasan utama digunakannya kalkulator dalam pengajaran matematika adalah bahwa waktu yang dibutuhkan untuk menyelesaikan masalah dapat digunakan untuk meningkatkan keterampilaan dalam menggunakan strategi pemecahan masalah.

5) Manajemen Kelas

Beberapa setting kelas yang mungkin dikembangkan antara lain model klasikal, dengan mengelompokkan siswa ke dalam kelompok kecil (small group cooperative learning) dan model belajar individual atau bekerja sama dengan anak lainnya (berdua). Aktivitas yang dikembangkan melalui kelompok besar (klasikal) dapat dilakukan terutama jika kita bermaksud mengembangkan strategi pemecahan masalah baru dan mencoba berbagai strategi untuk memecahkan soal yang sama.

Dengan mengelompokan siswa ke dalam kelompok-kelompok kecil memeberi peluang bagi mereka untuk mendiskusikan masalah yang dihadapi, saling tukar ide antar siswa, dan memperoleh alternatif pemecahan masalah yang bisa digunakan. Selain itu, dalam kelompok kecil, siswa dimungkinkan untuk mampu memecahkan masalah yang lebih baik dibanding kalau mereka bekerja sendiri-sendiri. Walaupun dengan bekerja bersama bisa memakan waktu lebih lama, akan tetapi hasil penelitian menunjukan bekerja secara kelompok, siswa mampu menunjukan kemampuan lebih baik dalam memahami permasalahan secara lebih mendalam.

Berdasarkan alasan tersebut dibutuhkan pembelajaran yang dapat melibatkan siswa secara aktif dengan baik. Model pembelajaran yang dapat melibatkan peran siswa secara aktif adalah model Pembelajaran Kooperatif. Menurut Slavin dalam Lie (2009), melalui model pembelajaran ini siswa dapat mengemukakan pemikirannya, saling bertukar pendapat, saling bekerja sama jika ada teman dalam kelompoknya yang mengalami kesulitan dan dapat meningkatkan pencapaian prestasi para siswa. Selain itu, tumbuhnya kesadaran bahwa para siswa perlu belajar untuk berpikir menyelesaikan masalah dan mengintegrasikan serta mengaplikasikan kemampuan dan pengetahuan mereka.

Pembelajaran kooperatif yang memberikan kesempatan kepada kelompok untuk membagikan dan mengkomunikasikan hasil kerja mereka dengan kelompok lain sehingga penyebaran informasi lebih meluas dalam kelas tersebut adalah pembelajaran kooperatif tipe TSTS. Pembelajaran kooperatif tipe TSTS memberikan kesempatan kepada kelompok untuk membagikan hasil dan informasi dengan kelompok lain. Model pembelajaran kooperatif dengan tipe TSTS dalam penelitian ini adalah salah satu tipe pembelajaran kooperatif yang didalamnya dibentuk kelompokkelompok heterogen yang baranggotakan 4 orang atau sering disebut dua tinggal dua tamu. Model pembelajaran kooperatif tipe TSTS (Two Stay Two Stray) atau dua tinggal dua tamu dikembangkan oleh Spencer Kagan (1990), salah satu kelebihan dari teknik pembelajaran kooperatif tipe TSTS (Two Stay Two Stray) ini yaitu mampu menciptakan dan menumbuhkan suasana belajar kelompok peserta didik untuk saling berbagi informasi dengan kelompok-kelompok peserta didik yang lain. Sehingga materi yang disampaikan oleh pendidik lebih menarik dan menyenangkan yang akan berdampak pada hasil belajar peserta didik (Ziyad, 2014). Menurut Saraswati (2012), salah satu model yang bisa diterapkan untuk meningkatkan pemecahan masalah matematis siswa adalah model pembelajaran tipe TSTS. Dengan adanya interaksi positif antar kelompok, maka akan melatih kemampuan siswa dalam pemecahan masalah, dan memacu terbentuknya ide baru serta memperkaya perkembangan intelektual siswa.

\section{METODE PENELITIAN}

Penelitian dilaksanakan di SD Negeri 136 Pekanbaru kelas V.B Tahun Ajaran 2014/2015. Jenis penelitian ini adalah Penelitian Tindakan Kelas (PTK). Penelitian tindakan kelas adalah penelitian yang dilakukan oleh guru di dalam kelasnya sendiri, dengan tujuan untuk memperbaiki 
kinerjanya sebagai guru sehingga hasil belajar siswa pada pemecahan masalah matematis siswa meningkat (Igak Wardani, 2007).

Instrumen yang digunakan dalam penelitian ini adalah Rencana Pelaksanaan Pembelajaran (RPP) dan lembar observasi kemampuan pemecahan masalah siswa sesuai indikator. Teknik analisis data yang digunakan pada penelitian ini adalah analisis statistik deskriptif. Statistik deskriptif adalah kegiatan statistik yang dimulai dari menghimpun data, menyusun atau mengukur data, mengolah data, menyajikan dan menganalisis data angka guna memberikan gambaran suatu gejala, peristiwa atau keadaan (Hartono, 2004). Pada penelitian ini, analisis statistik deskriptif bertujuan untuk mendeskripsikan tentang peningkatan kemampuan pemecahan masalah matematis siswa selama proses pembelajaran.

Adapun langkah-langkah yang ditempuh dalam PTK adalah mengikuti model yang dikembangkan oleh Kurt Lewin yang meliputi empat komponen yaitu: (1) perencanaan (planning), (2) pelaksanaan (implementing), (3) pengamatan (observing), (4) refleksi (reflecting). Keempat komponen tersebut membentuk suatu siklus, dan dalam pelaksanaannya kemungkinan membentuk lebih dari satu siklus yang mencakup keempat komponen tersebut.

\section{HASIL PENELITIAN DAN PEMBAHASAN}

Penyajian hasil penelitian yang dianalisis ialah kemampuan pemecahan masalah matematis siswa, yaitu kemampuan pemecahan masalah selama proses pembelajaran berlangsung secara individu dan perindikator dari proses pembelajaran Pra tindakan dan proses pembelajaran dengan tindakan menggunakan model Kooperatif tipe TSTS. Awal pengamatan pertemuan pertama proses pembelajaran dilakukan tanpa tindakan. Pertemuan berikutnya guru melakukan pengamatan dengan menggunakan tindakan sebanyak dua siklus. Pengamatan tanpa menggunakan model pembelajaran dan dengan menggunakan model Kooperatif tipe TSTS dilakukan dengan mengisi lembar pengamatan siswa dan sesuai dengan indikator pemecahan masalah yang telah disiapkan dan ditetapkan.

Hasil penelitian yang dilakukan di SD Negeri 136 Pekanbaru pada kelas V.B menunjukkan bahwa, hasil kemampuan siswa pada siklus I sebesar 20\%, siklus II sebesar 60\% sedangkan pada siklus III sudah terpenuhi sebesar $80 \%$. Seperti pada Tabel 1 berikut.

Tabel 1. Bobot Ketercapaian Indikator Kemampuan Pemecahan Masalah Matematis Siswa Selama Proses Pembelajaran

\begin{tabular}{|c|c|c|c|c|c|c|c|}
\hline \multirow{3}{*}{ No. } & \multirow{3}{*}{ Indikator } & \multicolumn{6}{|c|}{ Ketercapaian Selama Proses Pembelajaran } \\
\hline & & \multicolumn{2}{|c|}{ Pra Tindakan } & \multicolumn{2}{|c|}{ Siklus I } & \multicolumn{2}{|c|}{ Siklus II } \\
\hline & & $\%$ & Ket & $\%$ & Ket & $\%$ & Ket \\
\hline 1 & $\begin{array}{l}\text { Mengidentifikasi kecukupan data untuk } \\
\text { pemecahan masalah }\end{array}$ & 79 & $\mathrm{Ya}$ & 80 & $\mathrm{Ya}$ & 87 & $\mathrm{Ya}$ \\
\hline 2 & $\begin{array}{l}\text { Membuat model matematik dari suatu } \\
\text { situasi atau masalah sehari-hari dan } \\
\text { menyelesaikannya }\end{array}$ & 69 & Tidak & 79 & $\mathrm{Ya}$ & 83 & $\mathrm{Ya}$ \\
\hline 3 & $\begin{array}{l}\text { Memilih dan menerapkan strategi untuk } \\
\text { menyelesaikan masalah matematika } \\
\text { dan/atau di luar matematika }\end{array}$ & 63 & Tidak & 67 & Tidak & 76 & $\mathrm{Ya}$ \\
\hline 4 & $\begin{array}{l}\text { Menjelaskan atau menginterpretasikan } \\
\text { hasil sesuai permasalahan asal, serta } \\
\text { memeriksa kebenaran hasil atau jawaban }\end{array}$ & 67 & Tidak & 69 & Tidak & 74 & Tidak \\
\hline 5 & $\begin{array}{l}\text { Menerapkan matematika secara } \\
\text { bermakna }\end{array}$ & 75 & Tidak & 77 & $\mathrm{Ya}$ & 83 & $\mathrm{Ya}$ \\
\hline & Ketercapaian & $20 \%$ & Tidak & $60 \%$ & Tidak & $80 \%$ & $\mathrm{Ya}$ \\
\hline
\end{tabular}


Berdasarkan Tabel 1 di atas dapat dilihat bahwa nilai persentase ketercapaian kemampuan pemecahan masalah matematis siswa melalui tindakan lebih tinggi dari pada pra tindakan. Pada siklus I dan II ketercapaian motivasi belajar sebesar 20\% dan $60 \%$ berada pada kategori tidak memenuhi sehingga perlu siklus selanjutnya. Pada siklus III ketercapaian motivasi belajar sudah baik yakni sebesar 80\%. Sedangkan analisis tindakan untuk perorangan siswa selama proses pembelajaran dengan model kooperatif tipe TSTS sebagai berikut

Tabel 2. Pengelompokkan Bobot Ketercapaian Pemecahan Masalah Matematis Siswa per Indikator

\begin{tabular}{|c|c|c|c|c|c|c|}
\hline \multirow{3}{*}{ No. } & \multirow{3}{*}{$\begin{array}{l}\text { Kode } \\
\text { Siswa }\end{array}$} & \multicolumn{2}{|c|}{ Pra Tindakan } & \multicolumn{2}{|c|}{ Melalui Tindakan } & \multirow{3}{*}{ Keterangar } \\
\hline & & \multirow{2}{*}{ Total } & \multirow{2}{*}{$\begin{array}{c}\text { Persentase } \\
(\%)\end{array}$} & \multirow{2}{*}{ Total } & \multirow{2}{*}{$\begin{array}{c}\text { Persentase } \\
(\%)\end{array}$} & \\
\hline & & & & & & \\
\hline 1 & 1 & 22 & 73 & 24,3 & 81,1 & Meningkat \\
\hline 2 & 2 & 19 & 63 & 23,7 & 78,9 & Meningkat \\
\hline 3 & 3 & 20 & 67 & 23,7 & 78,9 & Meningkat \\
\hline 4 & 4 & 23 & 77 & 24,0 & 80,0 & Meningkat \\
\hline 5 & 5 & 22 & 73 & 23,3 & 77,8 & Meningkat \\
\hline 6 & 6 & 24 & 80 & 24,3 & 81,1 & Meningkat \\
\hline 7 & 7 & 23 & 77 & 24,7 & 82,2 & Meningkat \\
\hline 8 & 8 & 22 & 73 & 25,0 & 83,3 & Meningkat \\
\hline 9 & 9 & 24 & 80 & 25,3 & 84,4 & Meningkat \\
\hline 10 & 10 & 22 & 73 & 24,7 & 82,2 & Meningkat \\
\hline 11 & 11 & 21 & 70 & 24,7 & 82,2 & Meningkat \\
\hline 12 & 12 & 23 & 77 & 24,7 & 82,2 & Meningkat \\
\hline 13 & 13 & 22 & 73 & 24,7 & 82,2 & Meningkat \\
\hline 14 & 14 & 19 & 63 & 22,7 & 75,6 & Meningkat \\
\hline 15 & 15 & 20 & 67 & 23,0 & 76,7 & Meningkat \\
\hline 16 & 16 & 23 & 77 & 24,0 & 80,0 & Meningkat \\
\hline 17 & 17 & 22 & 73 & 23,7 & 78,9 & Meningkat \\
\hline 18 & 18 & 24 & 80 & 24,3 & 81,1 & Meningkat \\
\hline 19 & 19 & 23 & 77 & 24,0 & 80,0 & Meningkat \\
\hline 20 & 20 & 20 & 67 & 26,7 & 88,9 & Meningkat \\
\hline 21 & 21 & 20 & 67 & 24,7 & 82,2 & Meningkat \\
\hline 22 & 22 & 22 & 73 & 25,3 & 84,4 & Meningkat \\
\hline 23 & 23 & 16 & 53 & 24,7 & 82,2 & Meningkat \\
\hline 24 & 24 & 12 & 40 & 25,3 & 84,4 & Meningkat \\
\hline 25 & 25 & 15 & 50 & 22,0 & 73,3 & Meningkat \\
\hline 26 & 8 & 22 & 73 & 23,7 & 78,9 & Meningkat \\
\hline 27 & 9 & 24 & 80 & 23,3 & 77,8 & Meningkat \\
\hline 28 & 10 & 22 & 73 & 25,0 & 83,3 & Meningkat \\
\hline 29 & 11 & 21 & 70 & 24,0 & 80,0 & Meningkat \\
\hline 30 & 12 & 23 & 77 & 24,7 & 82,2 & Meningkat \\
\hline 31 & 13 & 22 & 73 & 26,3 & 87,8 & Meningkat \\
\hline
\end{tabular}




\begin{tabular}{lllllll}
\hline $\mathbf{3 2}$ & 14 & 19 & 63 & 22,3 & 74,4 & Meningkat \\
\hline $\mathbf{3 3}$ & 15 & 20 & 67 & 22,7 & 75,6 & Meningkat \\
\hline $\mathbf{3 4}$ & 16 & 23 & 77 & 23,7 & 78,9 & Meningkat \\
\hline $\mathbf{3 5}$ & 17 & 22 & 73 & 23,7 & 78,9 & Meningkat \\
\hline
\end{tabular}

Dari Tabel 2 di atas, menunjukkan bahwa secara umum setiap siswa mengalami peningkatan kemampuan pemecahan masalah matematis kelas V.B SD Negeri 136 Pekanbaru.

\section{KESIMPULAN}

Berdasarkan hasil penelitian, dapat diambil kesimpulan bahwa pembelajaran dengan model kooperatif tipe TSTS dapat meningkatkan kemampuan pemecahan masalah matematis kelas V.B SD Negeri 136 Pekanbaru. Ini terlihat dari ketercapaian bobot pada indikator.

Berdasarkan kesimpulan yang telah peneliti kemukakan, peneliti menyarankan untuk menggunakan model pembelajaran ini untuk meningkatkan hasil belajar siswa.

\section{DAFTAR PUSTAKA}

Trianto. (2012). Mendesain Model Pembelajaran Inofativ-progresif Jakarta: Kencana Grup.

Abdurrahman, Mulyono. (2012). Anak Berkesulitan Belajar. Jakarta: Rineka Cipta.

Wena, Made. (2011). Strategi Pembelajaran Inovatif Kontemporer Suatu Timjauan Konseptual Operasional.

Jakarta: Bumi Aksara.

Suyanto. (2012). Calon Guru dan Guru Profesional. Yogyakarta: Multi Pressindo.

Lie, Anita. (2009). Cooperative Learning Jakarta: Grasindo.

Saraswati dkk. (2012). "Penerapan pembelajaran two stay two stray (TSTS) terhadap kemampuan pemahaman konsep dan minat". Journal of Mathematics Education Unnes.

Suherman, Ermam. Strategi Pembelajaran Matematika Kontemporer. Bandung : JICA UPI. 2001.

Hartono. (2004). Statistik untuk Penelitian. Yogyakarta : $\mathrm{LSFK}_{2} \mathrm{P}$.

Uno, Hamzah B. (2008). Model Pembelajaran Menciptakan Proses Belajar Mengajaryang Kreatif dan Eektif. Jakarta : Bumi Aksara.

Wardani, Igak. (2007). Penelitian Tindakan Kelas. Jakarta : Universitas Terbuka.

Zakaria, Effandi. (2007). Trend Pengajaran dan Pembelajaran Matematik. Kuala Lumpur : Lohprint SDN. BHD.

Ziyad Habibi. (2014). "Pengaruh Model Pembelajaran Kooperatif Tipe Tsts (Two Stay Two Stray) Terhadap Hasil Belajar Siswa Pada Mata Pelajaran Teknik Elektronika Dasar Di Smk Negeri 1 Jetis Mojokerto". E-jourrnal UNESA, Vo. 3, No. 3. 